\title{
Fasilitasi peningkatan kompetensi wirausaha kuliner di era pandemi
}

\author{
Ujang Syahrul Mubarrok ${ }^{1 *}$, Nuraidya Fajariah ${ }^{2}$, Ahmad Yani $^{3}$ \\ ${ }^{1}$ Universitas Islam Kadiri, Kediri, Indonesia, email: ujang@uniska-kediri.ac.id \\ ${ }^{2}$ Universitas Islam Kadiri, Kediri, Indonesia, email: nuraidyafajariyah@uniska-kediri.ac.id \\ ${ }^{3}$ Universitas Islam Kadiri, Kediri, Indonesia, email: ahmadyani@uniska-kediri.ac.id \\ *Koresponden penulis
}

\section{Info Artikel}

Diajukan: 15 Des 2020

Diterima: 24 Apr 2021

Diterbitkan: 05 Mei 2021

Keywords:

community dedication; entrepreneur; management training; villagers

\section{Kata Kunci:}

pengabdian masyarakat; wirausaha; pelatihan manajemen; masyarakat desa

\section{Lisensi:}

cc-by-sa

\begin{abstract}
The Covid-19 pandemic has an impact on the sustainability of micro, small and medium enterprises, including the businesses of Ngasem residents which have been running so far. Also, businesses owned by residents of Ngasem Village have problems related to entrepreneurial motivation, business management, and limited knowledge about business bookkeeping. The purpose of this service is so that the training participants have a strong motivation to continue doing business, have knowledge of business management, and can manage and make simple business bookkeeping. This method of implementing this service uses lectures, discussions, and cooking practices. During the activity, the participants were very enthusiastic about participating in the training and several participants asked questions. The results of this service activity can increase motivation to continue to work hard, increase the ability of participants to make financial records, and deepen their skills in food processing.
\end{abstract}

Abstrak
Pandemi Covid-19 memberikan pengaruh terhadap keberlangsungan
usaha mikro, kecil, dan menengah, tak terkecuali bisnis warga
Ngasem yang selama ini berjalan. Selain itu juga, usaha yang dimiliki
warga Desa Ngasem memiliki masalah berkaitan dengan motivasi
berwirausaha, manajemen bisnis dan keterbatasan pengetahuan
tentang pembukuan usaha. Tujuan pengabdian ini adalah agar
peserta pelatihan memiliki motivasi yang kuat untuk terus berbisnis,
memiliki pengetahuan tentang manajemen bisnis, serta mampu
mengelola dan membuat pembukuan usaha secara sederhana.
Metode pelaksanaan pengabdian ini menggunakan ceramah, diskusi,
dan praktek memasak. Selama kegiatan berlangsung, para peserta
sangat antusias mengikuti pelatihan dan beberapa peserta
mengajukan pertanyaan. Hasil kegiatan pengabdian ini mampu
menambah motivasi untuk terus bekerja keras, meningkatkan
kemampuan peserta untuk membuat pencatatan keuangan, serta
memperdalam keahlian mengolah makanan.

\section{PENDAHULUAN}

Pandemi Covid-19 menjadi masalah global di dunia dengan jumlah kasus per 13 Desember 2020 sebanyak 72 juta kasus dengan 1,6 juta yang meninggal (www.worldometers.info). Merebaknya virus Covid-19 pertama kali terdeteksi di Wuhan, China yang dengan cepat menyebar ke seluruh penjuru 
dunia. Covid-19 memiliki daya tular yang cepat sehingga WHO menyatakan sebagai pandemi global sebagai tanggap darurat kesehatan masyarakat dunia (Livana et al., 2020).

Pandemi Covid-19 memberikan implikasi dalam bidang ekonomi, sosial dan politik hampir di seluruh negara. Perkembangan ekonomi global saat ini sedang mengalami kondisi yang buruk sejak awal 2020. Bank Dunia dan Dana Moneter Internasional melaporkan beberapa negara di dunia mengalami resesi yang sangat tajam. Pertumbuhan ekonomi global dapat merosot sampai minus 2,8\% (Nasution et al., 2020). Dampak pandemi juga berimbas kepada Indonesia di berbagai sektor, misalnya penerimaan pajak, investasi, dan nilai ekspor migas maupun non-migas mengalami penurunan (Nasution et al., 2020).

Dampak ekonomi akibat pandemi Covid-19 juga menggangu sektor Usaha Mikro, Kecil, dan Menengah (UMKM). Gangguan tersebut berupa kesulitan memperoleh bahan baku, penurunan omzet penjualan yang akan berujung kepada pengurangan kapasitas produksi bahkan sampai memberhentikan produksi (Sugiri, 2020). Dampak pandemi Covid-19 juga berpengaruh bagi perekonomian masyarakat desa. Livana et al. (2020) menyebutkan pengaruhnya berupa penurunan aktivitas ekonomi desa, penghentian semetara proyek infrastruktur desa, pembatasan aktivitas sosialpendidikan dan pemberhentian hubungan kerja.

Permasalahan tersebut juga dialami bagi UMKM yang ada di Kabupaten Kediri terutama di Desa Ngasem, Kecamatan Ngasem, Kabupaten Kediri. Sebuah desa yang terletak di pinggiran Kota Kediri tidak jauh dari ikon Kediri yaitu Simpang Lima Gumul. Aktivitas ekonomi warga desa Ngasem meliputi berbagai sektor seperti pegawai negeri, pegawai swasta, pertanian, pendidikan, makanan dan minuman. Usaha pada sektor makan dan minuman ada yang menggeluti catering, makanan ringan, kue dan minuman sari buah.

Berdasarkan informasi yang didapatkan, ada beberapa permasalahan yang dihadapi: (1) menurunnya semangat wirausaha karena situasi ekonomi yang melambat akibat pandemi; (2) pengelolaan bisnis masih tidak teratur baik pada produksi, distribusi dan mengelola SDM karena keterbatasan pengetahuan; dan (3) tidak adanya pembukuan dan pencatatan keuangan bisnis. Selain masalah berkaitan UMKM, Desa Ngasem juga mengalami masalah adanya warga pengangguran baru akibat pemutusan hubungan kerja. Masalah-masalah tersebut harus segera diselesaikan.

Oleh karena itu, perlu ada program untuk mengatasi masalah itu salah satunya dengan fasilitasi peningkatan kompetensi wirausaha. Fasilitasi tersebut berupa pelatihan manajemen usaha dan pengelolaan keuangan UKM bagi warga desa Ngasem, Kediri. Beberapa kegiatan pelatihan pernah dilakukan antara lain oleh Fauzi (2020) yang memberikan pelatihan manajemen keuangan bagi pelaku UMKM Jabar Juara. Rapini et al. (2020) mengusahakan strategi pengembangan produk Jipang berbasikan pelatihan manajemen usaha dan pemasaran yang kreatif pada BUMDes Jetis, Ponorogo. Sementara Rohim \& Kurniawan (2017) melakukan pelatihan manajemen usaha dan produksi pada UMKM di Desa Carang Wulung 
Jombang. Kurniawati et al. (2019) melakukan pengabdian pada Kelompok Usaha Bersama (KUB) Srikandi Semarang dengan topik pemasaran online. Pelatihan-pelatihan seperti yang disebutkan belum pernah dilakukan di Desa Ngasem Kediri.

Gambaran tersebut menjadi alasan diadakan pengabdian fasilitasi peningkatan kompetensi wirausaha dengan mengadakan pelatihan motivasi kewirausahaan, manajemen bisnis dan pengelolaan keuangan sederhana bagi Usaha Mikro Kecil dan Menengah (UMKM), penganggur serta setengah penganggur Desa Ngasem, Kediri. Tujuan pengabdian ini adalah agar peserta pelatihan memiliki motivasi yang kuat untuk terus berbisnis, memiliki pengetahuan tentang manajemen bisnis, serta mampu mengelola dan membuat pembukuan usaha secara sederhana.

\section{METODE PELAKSANAAN}

Metode pelaksanaan pengabdian untuk menyelesaikan masalah sebagaimana disebutkan pada pendahuluan meliputi:

\section{Perencanaan dan persiapan}

Tim PKM melakukan perencanaan dengan berkoordinasi dengan pihak yang terlibat mengenaai waktu dan tempat pelaksanaan acara. Pihak yang terlibat adalah Universitas Islam Kadiri, Dinas Tenaga Kerja kabupaten Kediri, Pemerintah Desa Ngasem dan LPK Elvita. Waktu pelaksanaan selama 2 hari yaitu tanggal 30 November 2020 dan 1 Desember 2020 yang bertempat di aula Balai Desa Ngasem. Peserta dalam kegiatan ini berjumlah 30 orang yang terdiri dari UKM sektor makanan dan minuman serta penganggur dan setengah penganggur dari warga desa Ngasem. Persiapan juga dilakukan dengan mengidentifikasi masalah yang dihadapi UMKM warga Desa Ngasem melalui wawancara dan observasi.

\section{Pelaksanaan}

Pelaksanaan pelatihan menggunakan metode ceramah, diskusi dan tanya jawab. Materi pelatihan meliputi motivasi kewirausahaan, manajemen bisnis dan pembukuan sederhana.

\section{Evaluasi Hasil}

Evaluasi hasil pelatihan dilakukan selama proses dan setelah kegiatan dilaksanakan. Evaluasi untuk menentukan kelebihan dan kekurangan pelaksanaan pelatihan demi perbaikan acara kedepan.

\section{HASIL DAN PEMBAHASAN}

Kegiatan pelatihan manajemen usaha dan pembukuan sederhana Desa Ngasem diikuti oleh 30 orang peserta. Aktivitas peserta dimulai dengan melakukan registrasi dan memasuki gedung aula menunggu acara dimulai. Pelaksanaan kegiatan diawali dengan pembukaan acara yang dihadiri oleh Camat, Kepala Desa, Babinsa dan perwakilan dari Disnaker Kabupaten Kediri. Bapak Camat Ir. Ary Budianto dalam sambutannya mengingatkan kepada ibu-ibu peserta pelatihan untuk tidak melupakan kodratnya sebagai 
wanita ketika menjadi pengusaha. "Wanita adalah ibu rumah tangga yang harus berbakti kepada suami dan mendidik anak" ujar bapak Camat.

Sementara Kepala Desa Ngasem Yuhari dalam sambutannya mengharapkan keseriusan para peserta dengan mengikuti pelatihan sampai selesai. Kepala Desa Ngasem juga menyatakan "hasil produksi para peserta nantinya ditampung oleh pusat oleh-oleh yang ada di rest area milik Desa Ngasem".

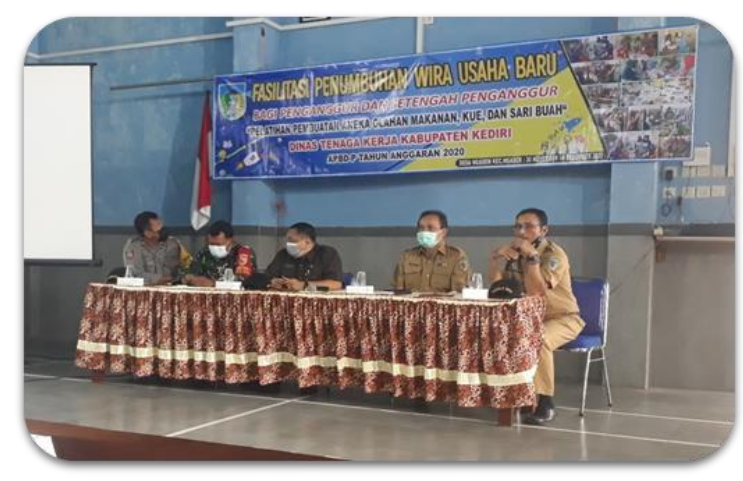

Gambar 1. Pembukaan acara

Setelah pembukaan kemudian dilanjutkan penyampaian materi mengenai motivasi kewirausahaan, manajemen bisnis dan pengelolaan keuangan sederhana. Materi motivasi kewirausahaan perlu disampaikan untuk memberikan semangat kepada para peserta untuk terus berusaha mengembangkan bisnisnya. Poin-poin materi yang disampaikan pada sesi yang dibawakan oleh Ujang Syahrul Mubarrok SE., MM ini adalah perbedaan antara pegawai dan pengusaha, alasan untuk berwirausaha, karakteristik dan mental wirausahawan, cara menggali ide memulai usaha. Pada sesi diskusi salah satu peserta yang bernama Hasan Muhammad mengungkapkan alasan pilihan hidupnya menjadi entrepreneur adalah, "karena terpaksa hanya memiliki ijazah SMA, melamar menjadi pegawai tidak diterima. Menjadi pengusaha juga enak, bebas menentukan waktu kerja".

Pemateri juga menyampaikan beberapa alasan menjadi wirausaha, yaitu (1) alasan keuangan untuk memperoleh penghasilan dan menghidupi keluarga; (2) alasan sosial demi menjaga harga diri dengan bekerja karena sudah dewasa; (3) alasan pelayanan dengan membuka lapangan kerja membantu para pengangguran; (4) alasan agama yang menganjurkan setiap umat Islam untuk bekerja dan mencari nafkah yang halal.

Motivasi kewirausahaan sangat diperlukan bagi pengusaha karena dapat menambah percaya diri dan semangat untuk melanjutkan hidup semakin produktif (Indrawati et al., 2020; Khoiryasdien \& Annisa Warastri, 2020), serta menjaga agar tidak mudah putus asa dalam menjalankan usahanya (Winarno et al., 2020). 


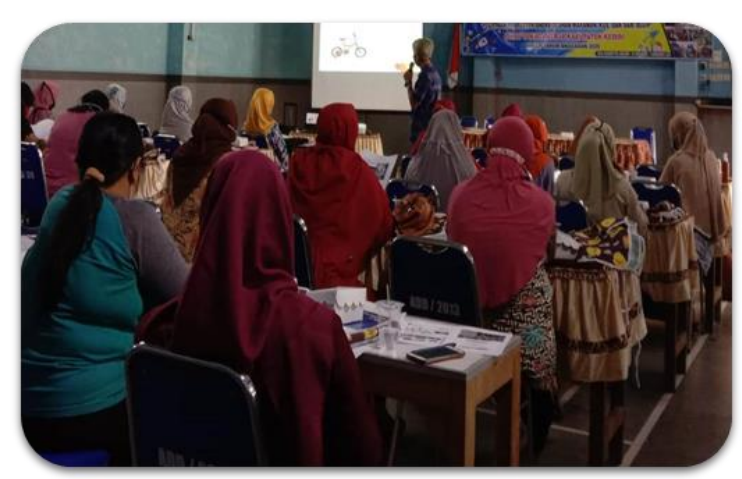

Gambar 2. Penyampaian motivasi kewirausahaan

Materi manajemen usaha disampaikan oleh Nuraidya Fajariah, SE., MM dengan membahas tentang manajemen produksi, sumber daya manusia, dan pemasaran. Manajemen produksi meliputi pentingnya inovasi dan pemilihan vendor yang tepat untuk keberlangsungan usaha. Pemateri memutarkan video perbandingan Gudeg Bu Tjitro yang berdiri sejak tahun 1925 dan Gudeg Mbah Lindu yang telah berjualan sejak tahun 1935. Video ini memperlihatkan bahwa Gudeg Bu Tjitro melakukan inovasi terhadap kemasan gudeg dengan memanfaatkan teknologi pengemasan kaleng. Oleh karenanya Gudeg Bu Tjitro dapat dikirim hingga keluar daerah dan lebih pantas jika dijadikan oleh-oleh khas Yogyakarta.

Terbalik dengan Gudeg Bu Tjitro, Gudeg Mbah Lindu tidak dikemas kalengan, hanya dijual dibungkus biasa yang membuat gudegnya tidak tahan lama. Video ini mampu menggugah keingintahuan peserta pelatihan akan pentingnya pemanfaatan teknologi untuk menyokong bisnis, terbukti dari beberapa peserta menceritakan keunggulan kemasan produk miliknya. Mengenai pemilihan vendor atau penyedia bahan baku dengan harga termurah, kualias terbaik, dan dapat menyediakan bahan baku terus menerus juga penting bagi kelangsungan usaha. Hal ini penting karena ketersediaan bahan baku adalah modal untuk memproduksi suatu produk, jika ketersediaan bahan baku ini terhambat, maka proses produksi akan mengalami kemacetan yang berakibat pada konsumen beralih pada merek yang tersedia karena lelah menunggu. Oleh karenanya, pemateri menyarankan untuk survei vendor pada beberapa pasar dan memilih beberapa vendor yang sesuai, sehingga jika salah satu vendor tidak dapat memenuhi bahan baku, pengusaha masih ada pilihan vendor yang lainnya.

Topik berikutnya yang disampaikan adalah mengenai pengolahan sumber daya manusia. Pada topik ini pemateri menyampaikan cara-cara untuk menarik karyawan yang baik dan dapat memanfaatkan media sosial untuk mencari karyawan yang sesuai. Disini peserta juga antusias, beberapa menceritakan pengalamannya mengenai karyawan. Umunya proses pencarian karyawan yang dilakukan oleh warga Desa Ngasem masih dari mulut ke mulut atau rekomendasi tetangga, dan jika beriklan masih melalui media Whatsapp. Disini warga mengungkapkan keluhan, yaitu sulitnya 
mempertahankan karyawan karena karyawan sering keluar masuk atau kurang loyal terhdap usaha. Pemateri memberikan arahan agar saat proses penarikan karyawan lebih teliti, salah satunya saat proses wawancara harus dilihat baik-baik apakah calon karyawan benar-benar membutuhkan pekerjaan atau hanya main-main. Pemateri juga menyarankan agar memberi pengarahan pada karyawan dengan bahasa yang baik, jelas, tegas, namun santai. Tidak lupa, karyawan juga harus dimotivasi dan diapresiasi kinerjanya, bisa melalui pujian atau pemberian insentif supaya karyawan lebih bersemangat dalam bekerja sehingga akan bekerja dengan lebih sungguhsungguh serta dapat meningkatkan loyalitas kerja karyawan.

Topik selanjutnya yang disampaikan adalah mengenai pemasaran produk. Kotler \& Keller (2007) mendefinisikan pemasaran adalah suatu proses sosial dan manajerial yang membuat individu dan kelompok memperoleh apa yang mereka butuhkan serta inginkan lewat penciptaan dan pertukaran timbal balik produk dan nilai dengan orang lain. Pemaparan mengenai pemasaran dimulai dari cara memilih segmen pasar serta posisioning produk yang tepat, hingga pentingnya menjaga kualitas produk. Pemateri mengungkapkan, banyak strategi yang dapat diterapkan untuk meningkatkan penjualan dari sisi produk, yakni melalui kemasan yang menarik, ukuran kemasan, dan rasa yang variatif. Pemateri memutarkan video dari It's Milk, kafe susu asal Semarang. Video ini memperlihatkan bahwa bahan yang biasa (susu) dapat tercipta berbagai produk yang variatif dan menarik minat konsumen jika diberi tambahan variasi rasa. Tidak kalah pentingnya, promosi juga memegang peran yang penting bagi keberlangsungan usaha. Umumnya, peserta pelatihan telah melakukan promosi, walaupun belum secara intensif. Promosi yang dilakukan meliputi komunikasi getuk tular, status whatsapp, dan facebook.

Pada masa kini terlebih pada masa pandemi, pemasaran produk lebih aktif pada media sosial. Di Indonesia, pengguna sosial media mencapai 160 juta pengguna pada tahun 2020 dengan Sebagian besar pengguna Youtube, Facebook dan Instagram (Hootsuite \& We are Social, 2020). Oleh karenanya, Instagram pada saat ini memiliki peluang untuk mempromosikan produk yang baik. Beberapa strategi dapat di terapkan guna mengoptimasi Instagram guna menaikkan follower. Diantaranya adalah dengan menggunakan Instagram for business, melakukan postingan yang menarik, bermanfaat, dan rutin, meningkatkan audience untuk berpartisipasi, membalas postingan, kerja sama dengan influencer, update instastory, menggunakan hastag yang tepat, memberikan giveaway, dan memposting pada jam aktif follower. Guna menunjang promosi media sosial, sebaiknya menggunakan foto yang baik agar lebih menarik konsumen karena bisa menampilkan detil-detil barang. Tidak perlu menggunakan kamera professional, menggunakan kamera handphone pun dapat karena kamera handphone pada saat ini sudah cukup baik kualitasnya. 


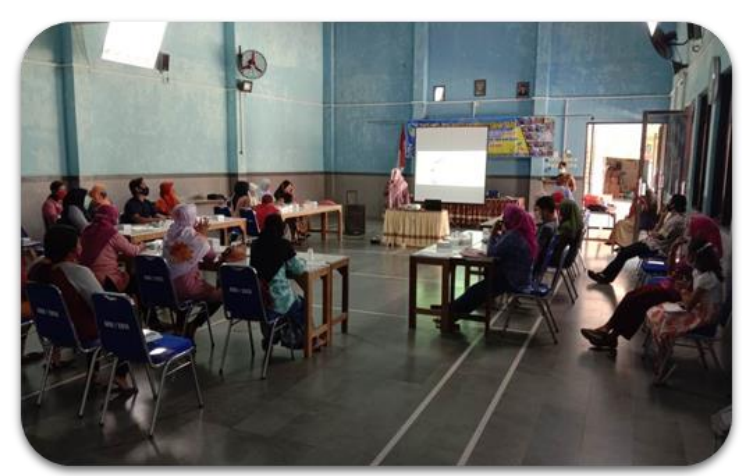

Gambar 3. Penyampaian materi manajemen usaha

Materi pembukuan sederhana menjadi materi pamungkas dalam pelatihan yang disampaikan oleh Ahmad Yani SE., MM. Para peserta masih antusias memperhatikan materi yang disampaikan berkaitan dengan (1) perhitungan Harga Pokok Produksi (HPP) untuk menentukan harga jual produk; (2) pencatatan keuangan arus kas baik pemasukan maupun pengeluaran uang; (3) perhitungan laba rugi untuk memberikan informasi aktivitas penjualan, beban, laba dan rugi; serta (4) cara menyusun laporan keuangan neraca secara sederhana.

Pemateri menyampaikan hal terpenting bagi pengusaha UMKM adalah memisahkan antara keuangan pribadi dan keuangan usaha. Jangan sampai keduannya dicampur sehingga sering uang usaha ikut digunakan kepentingan pribadi. Selain itu sebisa mungkin untuk mencatat setiap transaksi baik uang masuk maupun keluar.

Pada saat sesi pertanyaan, salah satu peserta menanyakan tentang bagaimana cara menentukan harga jual. Pemateri menjawab bahwa menetukan harga jual diawali dari menghitung berapa biaya yang digunakan untuk produksi dan berapa keuntungan yang akan diambil. Keduanya kemudian ditambahkan untuk menjadi harga jual.

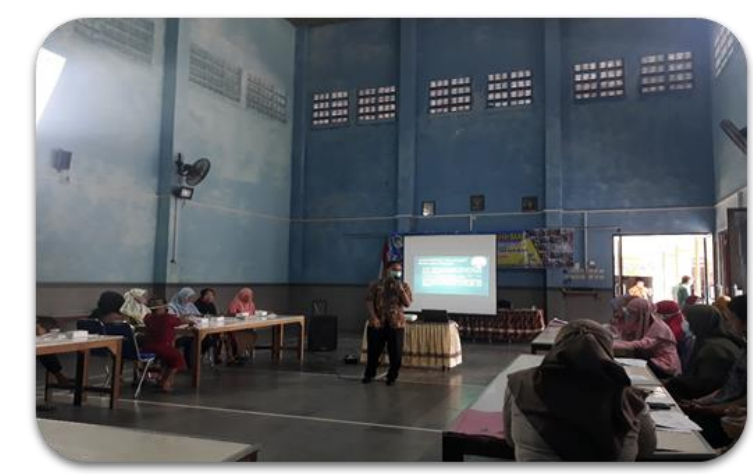

Gambar 4. Penyampaian materi pengelolaan keuangan sederhana

Setelah pelaksanaan acara kemudian di evaluasi secara menyeluruh berkaitan dengan pelaksanaan acara, pemateri, materi, dan respon peserta. 
Secara keseluruhan pelaksanaan acara berjalan lancar meskipun acara dimulai terlambat 1 jam tidak sesuai dengan waktu yang dijadwalkan. Pemateri sukses menyampaikan materi secara menarik. Materi sudah mencukupi sesuai dengan yang dibutuhkan peserta. Dan Peserta antusias merespon dengan mengajukan pertanyaan sehingga ada peningkatan pemahaman dan pengetahuan peserta mengenai manajemen bisnis dan pembukuan sederhana.

\section{KESIMPULAN}

Kegiatan pengabdian masyarakat berupa pelatihan motivasi kewirausahaan, manajemen bisnis dan pengelolaan keuangan sederhana bagi Usaha Mikro Kecil dan Menengah (UMKM), penganggur serta setengah penganggur Desa Ngasem, Kediri berjalan dengan lancar. Para peserta antusias dalam memperhatikan penyampaian materi dan beberapa peserta mengajukan pertanyaan. Hasilnya adalah pemahaman dan pengetahuan peserta pelatihan sebagai mitra pengabdian menjadi bertambah, dan sangat berguna dalam usaha mengembangkan bisnis mereka.

Saran yang dapat diberikan untuk pengabdian serupa adalah metode pelaksanaan selain seminar, diskusi dan praktek memasak, juga memberikan pendampingan selama beberapa bulan agar mitra pengabdian berhasil dalam mengembangkan usahanya.

\section{UCAPAN TERIMA KASIH}

Ucapan terima kasih penulis sampaikan kepada Lembaga Penelitian dan Pengabdian Masyarakat (LPPM) Universitas Islam Kadiri, Dinas Tenaga Kerja Kabupaten Kediri dan Pemerintah Desa Ngasem, Kecamatan Ngasem Kabupaten Kediri yang telah membantu terlaksananya pengabdian ini.

\section{DAFTAR RUJUKAN}

Fauzi, H. (2020). Pelatihan Manajemen Keuangan Bagi Pelaku UMKM Sebagai Upaya Penguatan UMKM Jabar Juara Naik Kelas. BERNAS: Jurnal Pengabdian Kepada Masyarakat, 1(3), 247-255. https://doi.org/10.31949/jb.v1i3.324

Hootsuite, \& We are Social. (2020). Digital 2020: Indonesia. Https://Datareportal.Com/Reports/Digital-2020-Indonesia.

Indrawati, A., Barus, I. N. E., Solihin, D., \& Nurqamarani, A. S. (2020). Peningkatan Motivasi Kewirausahaan dan Kemandirian Melalui Pelatihan Segmentasi Pasar. Jurnal Abdimas Mahakam, 4(1), 8-13. https://doi.org/10.24903/jam.v4i1.541

Khoiryasdien, A. D., \& Annisa Warastri. (2020). Pelatihan Motivasi Berwirausaha Pada Survivor Bipolar di Komunitas Bipolar Care Indonesia Simpul Yogyakarta. Jurnal Pengabdian Untuk Mu NegeRI, 4(1), 115-119. https://doi.org/10.37859/jpumri.v4i1.1551

Kotler, P., \& Keller, L. (2007). Manajemen Pemasaran, Jilid I, Edisi Kedua Belas. PT. Indeks.

Kurniawati, E., Santoso, A., \& Widowati, S. Y. (2019). Pelatihan Pemasaran 
Online Bagi Kelompok Usaha Bersama (KUB) "SRIKANDI". Jurnal Inovasi Hasil Pengabdian Masyarakat (JIPEMAS), 2(2), 132-138. https://doi.org/10.33474/jipemas.v2i2.2722

Livana, Suwoso, R. H., Febrianto, T., Kushindarto, D., \& Aziz, F. (2020). Dampak Pandemi Covid-19 bagi Perekonomian Masyarakat Desa. Indonesian Journal of Nursing and Health Sciences, 1(1), 37-48. https://doi.org/https://orcid.org/0000-0002-4905-7214

Nasution, D. A. D., Erlina, E., \& Muda, I. (2020). Dampak Pandemi COVID-19 terhadap Perekonomian Indonesia. Jurnal Benefita, 5(2), 212. https://doi.org/10.22216/jbe.v5i2.5313

Rapini, T., Kristiyana, N., Santoso, A., \& Setyawan, F. (2020). Strategi pengembangan produk jipang berbasiskan pelatihan manajemen usaha dan pemasaran yang kreatif. Masyarakat Berdaya Dan Inovasi, 1(1), 12-18. https://doi.org/https://doi.org/10.33292/mayadani.v1i1.7

Rohim, A., \& Kurniawan, I. (2017). Manajemen Usaha Dan Produksi Pada Usaha Mikro, Kecil Dan Menengah (UMKM) Di Desa Carang Wulung Wonosalam. Comvice: Journal of Community Service, 1(1), 23-28. https://doi.org/10.26533/comvice.v1i1.116

Sugiri, D. (2020). Menyelamatkan Usaha Mikro, Kecil dan Menengah dari Dampak Pandemi Covid-19. Fokus Bisnis: Media Pengkajian Manajemen Dan Akuntansi, 19(1), 76-86. https://doi.org/10.32639/fokusbisnis.v19i1.575

Winarno, A., Agustina, Y., Wijijayanti, T., Churiyah, M., \& Subagyo, S. (2020). Pelatihan Manajemen dan Pembukuan Dasar Bagi IKM Sanan Kota Malang. Jurnal KARINOV, 3(1), 58. https://doi.org/10.17977/um045v3i1p58-63

www.worldometers.info. (2020). Coronavirus Updates. 